\title{
An Institutional Management Crisis Research In Social Media: Soma Case
}

\author{
Ertekin İ. ${ }^{1}$, Ilgın, H.Ö. ${ }^{2}$, Yengin, D.A. ${ }^{3}$ \\ 1 Irfan ERTEKIN, Istanbul Aydin University, (Turkey) \\ ${ }^{2}$ Hicran Özlem ILGIN, Istanbul Aydin University, (Turkey) \\ ${ }^{3}$ Didem Ataman YENGIN, Istanbul Aydin University, (Turkey) \\ e-mail: irfanertekin25@gmail.com
}

\begin{abstract}
The news related to the Case in which 301 workers lost their lives as result of gas poisoning in Soma Coal Mine on May 14, 2014 was screened on the Internet news portals of 3 newspapers with large circulation rates in social media journalism in Turkey, and the aforementioned news was discussed in terms of experienced institutional crisis management. The primary purpose to carry out this research was to predict that an institutional management crisis was experienced in terms of coal company related to the aforementioned Case and to reveal this Case in terms of social media journalism using content analysis. The research was a "Screening Research" in terms of providing and using information. The research was carried out through "Content Analysis" method. The aforementioned review was performed upon news and comments related to the institutional management crisis relevant to "Soma Case" as the research subject. Each word and sentence in news and comments related to "Soma Case" between 14.05.2014 and 12.08.2014 time period in archives were included into the research. Aforementioned screening was performed in the archives of Milliyet, Hürriyet and Newstürk social media newspapers, respectively, depending upon "the first 100 news sites clicked most in Turkey" decided by Comscore in 2013 and 2014. As a result of screening, it was concluded that totally 965 pieces of news related to "Soma Case" were determined to be included, and 86 pieces of news among these were related to the Soma coal management crisis.
\end{abstract}

Keywords: Social Media, Soma Case, Institutional Management Crisis

\section{Introduction}

Based on the saying of famous physician Feynman who has the Nobel Prize, the fact that a driver has not experienced an accident for many years, and an organization having not experienced any important crises do not mean that everything will go on in the desired manner in future years. It is always possible that individuals as well as institutions face unwanted situations. The most important thing is being prepared for these risks, developing precautions and managing crises. Because crises may cause that the reputation of the organization is lost or it is wiped out of the sector. The only way to fight against crises and convert them into opportunities is accepting the reality of the crises, and having a crisis plan. The crisis and crisis communication plans must be improved by producing various scenarios to manage crises because every crisis has the possibility of leading to new crises as well as being converted into opportunities. In other words, crisis management is in fact one of the most important functions of institutional communication.

When the other fields listed within the responsibility field of the institutional communication are considered, it is observed that the following areas are included in this list; public relations, investor relations, internal communication, social relations, advertisement, relations with the media, relations with the government, employee development and education, institutional charity, crisis and emergency communication, problem management, institutional advertisement and institutional defensiveness, marketing communication, financial communication, change communication and institutional design (Görkem, 2013: 3). Institutions, companies or factories that are active in the field of manufacturing must use their public relations units as a tool to overcome possible management or economic crises, which may possibly appear in any time of their life spans, by making use of these units at the highest level. In other words, in one sense, both the communication within the corporation and with the masses outside the corporation must be managed well. Otherwise, it will be very difficult for them to succeed and develop. When the situation in practice is considered, it is observed that specialization is 
the basis of the communication with the target masses; and communication is divided into functional sub-units and run by these units (Görkem, 2013: 1).

Companies develop alternative plans in order to avoid crisis, or in other words, to prevent any types of difficulties or problems, and try to run for their future targets. For this reason, they create possible plans, programs and application strategies against crises before they actually happen. When the word crisis is mentioned, the first thing that crosses the mind is a crisis about economy. However, with the acceptance of the term "crisis" in the public relations literature, not only an economic crisis is understood but also the term connotates management crisis or institutional management crisis. The communication element is in an important position among these efforts.

Private or public institutions are under the influence of planned or unplanned communication in areas from daily work flow to significant change programs, from the creation of a positive institutional atmosphere and institutional culture to making manufacturing processes be adopted, from improving human resources to increasing performance, in other words, in all institutional activities and management processes (Tunçel, 2007: 1). In fact, this is actually the management of institutional communication in one sense. Efficient communication is or great importance for an institution (organization) since managers allocate a great deal of their time to communication in order to achieve success in management functions (Karcıoğlu et al., 2009: 65). For the purpose of overcoming a crisis, an efficient and accurate intra-institutional communication is always a vital element.

When considered in this aspect, it is possible to claim that the term crisis has been accepted in the public relations literature with the efforts of Ivy Lee, who is an important public relations specialist. Especially the Rockefeller management crisis is one of the best examples for this. The following list shows the applications in which Ivy Lee was involved generally in a successful manner about crisis management (Peltekoğlu, 2012: 448-449).
a. Anthracite Coal Strike,
b. Pennsylvania Railroads Crisis,
c. Colorado Coal Strike,
d. Rockefeller Management Crisis.

Ivy Lee took direct part in these crises. In this respect, it is possible to see how the crises were managed in what kind of planning and which results were achieved. Being prepared for crises, taking precautions and being able to manage crises are required to avoid the loss of reputation of the organization. Right at this point, the organization must admit the crisis and have a plan to manage it. It is possible to convert a crisis into opportunity with an institutional crisis program that is managed well (Peltekoğu, 2012: 448-450).

In order to speak of an institutional crisis, it is required that the reputation of the company is shaken, there must be limited time to resolve the problem, and the problems must appear in an unexpected time.

Both public and private institutions have to be prepared for any kind of negative opinions, perceptions, images or phenomena that might appear in the minds of the internal and external stakeholders, and take the required precautions to create and sustain an institutional reputation. Based on this point, the issues of how often the institutional management crisis in the case that happened in Soma Coal Mine on May 14, 2014 took place and how it was interpreted in social media will be the main points of our study.

\subsection{The Target Audience in Institutional Crisis Management and Crisis Communication}

In general terms, the word crisis represents a case that develops unexpectedly and suddenly. Institutions or organizations may not predict sudden crises. However, organizations that manage communication with internal and external target audience well may overcome crises with the smallest possible damage. Crisis in institutional sense may be considered as an unexpected situation with fast changes that has the property of eliminating the risk-prevention precautions of the organization and that threatens the purposes and existence of the institution (organization), and that requires urgent attention of the organization. It is a tense situation that affects the planning and decision-making mechanisms of an organization in a negative way. A crisis is also known as the breakthrough for an 
organization that will enable it to acquire new experiences and convert these experiences into opportunities (Demirtaş, 2000: 359).

In order for a change that emerges to be defined as a crisis, the following properties must exist (Asunakutlu et al., 2003: 143):

-A crisis cannot be predicted.

-The prediction and prevention mechanisms of the organization for crises are inadequate in the face of a

crisis.

-A crisis threatens the purpose and existence of the organization.

-There is no adequate information and time to decide which ways to follow in the face of a crisis in

order to overcome it.

-A crisis requires urgent intervention.

-A crisis causes tension in decision-makers.

Crises are times of danger; however, they may also be converted into opportunities. When organizations are ready for crises, and when they apply the strategic targets they develop in a fast manner, they may make use of crises. As a conclusion, a crisis may also be defined as a process through which organizations and managements are tested (Patan, 2009: 4).

Institutional crisis is a scene that appears after a sudden event or a pattern of events, and causes that the reputation of the organization is lost in an unexpected moment. An organization whose reputation is at risk may face extinction in the market. Right at this point, alternative crisis plans must be present and applied when necessary by considering the present risk in the context of a professional management concept. In today's world where global communication exists, there are no companies or countries that do not have the risk of facing institutional crisis. Each organization that is aware of this fact must have prepared risk analysis plans and have alternative plans ready at hand. Organizations must respond to four basic questions in order to be able to analyse crises in a systematic manner (Örnek and Aydın, 2006: 12).

1. What is a crisis or what kind of crises are there?

2. When did the crisis start?

3. Why did it occur?

4. Who were affected?

In case these four basic questions are not responded by the organizations that face the crisis in a detailed manner to inform the public, the organization will become the target of cruel criticisms by the target audience both in and outside the organization in social media, which is the indispensable and new media commination means in the $21^{\text {st }}$ Century, which is also called as the Digital Age both in written and in verbal fields. The way to be efficient during crisis communication passes through determining the target audience accurately, which is also the case in normal circumstances. In this context, the audience that is exposed to a crisis, the target audience both inside and outside the organization, and the media must be evaluated in separate positions. The communication with each target audience must be performed in separate channels, i.e. with separate tools (Peltekoğlu, 2012: 471).

Determining and classifying the target audience in an accurate manner will increase the efficiency of the public relations activities, and the organization will pinpoint the exact corrective action to revive the institutional reputation. For this reason, determining the target audience in institutional crisis management and performing activities that are proper for the target audience appear before us as an important step for the future of the organization. The media and relevant relations that are considered in the context of target audience are important topics that must be emphasized and focused on. However, institutional communication is extremely important in determining the target audience in an accurate manner. As mentioned by James E. GRUNIG, in order to be able to speak of an efficient organization, public relations and institutional public relations concepts, which in fact, we name as institutional communication, have vital importance. Farace, Monge and Rusell explained the importance of this point as follows. The communication system of an institution (organization) becomes a stronger determinant for the general efficiency level of it, and it may be considered that it has a limiting effect on sustaining its activities and on the survival of it. 
Showing especially to the media that the organization has taken control of the crisis and acting in this direction is extremely important. Previous relations established with the media before the crisis will be the advantage of the organization during a crisis. The media will have an important role in eliminating a crisis and clearing the effects of it. In this respect, in the present study, the reflections of the crisis in Soma Mine in the media will be investigated.

\subsection{The Hypothesis of Determining the Agenda}

The eponyms of the Hypothesis of Determining the Agenda are Maxwell E. McCombs and Donald L. Shaw. During the elections for presidency in the United States of America (the USA) in 1968, these writers conducted a study to investigate whether there was a relation between the order of priority in the agenda of the media and the order of priority of the same titles in the minds of the floating voters in Chappell Hill. The scientists defined the "Determining the Agenda" concept, and explained it as "the function of the mass media" (Yüksel, 2007: 577). Especially today, people ensure their connections with the world through social media channels.

Social media not only has the quality of "being the carrier of news", but it also has the function of guiding the public opinion on what to think and how to think. There are no humans on earth that exist without establishing communications. In brief, it is possible to say, "living without commination is not possible". Based on this point, a person who follows the contents of the media also receives the news in the way it is conveyed by the conveyor, in other words, in the way that is reflected by the sender. In this respect, it is possible to claim that social media defines the agenda, or it creates agenda, or even it establishes the agenda.

Today, individuals may use the social media platforms with the help of the Internet, and they may establish communications and interactions through these platforms according to their likes and demands. Since the social media platforms are extremely various, different types of media have emerged. It is possible to group them in the field of social media as follows; Facebook, MySpace, Linkedln, Friendster, Hi5, Friendfeed, Formspringa, and Xing. It is also possible to group these media in the field of blogs as follows; company blogs, Cnet, The Huffington Post, BoingBoing, Techcrunch, and Kottke. In addition to these, the following are the examples for social networks that enable individuals to share their videos; Youtube, Dailymotion, Google Videos, Yahoo Video It's on (Gül and Cengiz, 2016: 359).

The Hypothesis of Determining the Agenda is based on the idea that mass communication means may have an effect on the public opinion by emphasizing certain topics and by ignoring some others (Mc Quail and Windahl, 1993: 91).

Studies on how the agenda of the media is formed and under which influences they are created constitute the media sociology and news sociology fields. Studies in the field of media sociology investigate the external factors in the formation of the agenda of the media (political government, economic powers, etc.), and studies conducted in the field of news sociology investigate the values, beliefs and traditions in the profession of journalism, which is a limited field (Narrated by Kuyucu; Atabek, 1998: 22).

The Hypothesis of Determining the Agenda has been a mass communication hypothesis that influenced the communication studies at a great deal, and many studies have been conducted on it so far. The studies conducted on the effective field of communication in 1920s accelerated the development of this hypothesis. In the field of communication, the first studies conducted on the effects of mass communication means on receivers / viewers / readers show that this effect is strong. In studies conducted in 1950s; however, it was concluded that the effect was reduced (Kuyucu, 2016: 333).

In this context, the frequency of the news on the crisis about the Soma Case in social media was investigated with the Content Analysis Method. The Hypothesis of Determining the Agenda is separated into two models. The first model is Mc Combs Shaw's basic model, and the second model is the "determining the agenda model" based on differences proposed by Rogers and Dearing. According to the "determining the agenda model" of McCombs Shaw, the topics that are cared much in mass communication will be perceived as the most important topics. In this model, the data that will 
be obtained by measuring the amount how much the mass communication means allocate time and place are closely related with the interest of the public in the same topic or with their judgments on the importance of the relevant topic.

In the present study, the extent of the effect of the Soma Case on the public was investigated with the Content Analysis Method. Right at this point, it must be born in mind that the important thing is to investigate the issue of how frequently the "Soma Case" became news in the social media rather than investigate the effect of the relevant news. The issue of measuring the effect of the news in the light of the Hypothesis of Determining the Agenda is the topic of a separate study.

\subsection{Material and Method}

The study involves the investigation of the Institutional Management Crisis about the disaster in Soma Coal Mine on May 14, 2014 in social media. The news on the Institutional Management Crisis that occurred as a result of the deaths of 301 employee due to gas poisoning in the Coal Mine in Soma on May 14, 2014 was reviewed in the light of the data that were obtained in the Internet news portals of the 3 newspapers that had the highest circulation rates in the field of social media journalism in Turkey. It has been foreseen that an institutional management crisis appeared as a result of the deaths of 301 employee due to gas poisoning in the Coal Mine in Soma on May 14, 2014.

The study is a "Review Research" in terms of the collection and analysis of the data. The study was conducted with the "Internet Media Review" and "Content Analysis" methods. The study on the Soma Case was conducted by reviewing the news and interpretations on the Internet news portals of 3 (three) newspapers that had the highest circulation rates in the field of social media in Turkey. The reviews were made on the news and interpretations about the institutional management crisis on the "Soma Case", which is the subject of the present study. The archives of the newspapers were made use of in the study, which was conducted in the Internet Media Review method. The relevant time periods of the archives were selected on the calendar, and each word and sentence in the news and interpretations which were related with the "Soma Case" were included in the universe of the study.

The news and interpretations about Soma were investigated with the Content Analysis Method. The study will be limited between the dates 14.05.2014 and 12.08.2014, because, as of 12.08.2014, the elections of presidency constituted the main agenda of Turkey; and therefore, it was observed that there was no news and interpretations anymore about the "Soma Case" in social media. The review, which was made in the context of Hypothesis of Determining the Agenda, was performed by reviewing the archives of Milliyet, Hürriyet and Newstürk social media newspapers, which are clicked with the highest rates in Turkey according to the data provided by Comscore for the dates between 2013 and 2014 January. The findings of the study were reached by reviewing the archives of Milliyet, Hürriyet and Newstürk social media newspapers and by using the Content Analysis Method.

\subsection{Basic Assumption}

It was assumed that there was an institutional crisis by supposing that it was not managed well after the death of 301 coal mine employees in Soma Coal Mines on May 14, 2014.

\subsection{Analysis and Findings}

The required findings for the study were obtained by performing an analysis on the discourses in the news on the management crisis on the Soma Case in the archives of the Milliyet, Hürriyet and Newstürk newspapers, which have the highest circulation rates in Internet journalism (Tables 1, 2, and 3).

Table 1. Milliyet Internet Newspaper News Content Analysis and Findings (14.5.2014-12.8.2014)

\begin{tabular}{|c|c|c|c|}
\hline Month & $\begin{array}{c}\text { The News on } \\
\text { Soma }\end{array}$ & News Topics & $\begin{array}{c}\text { Management } \\
\text { Crisis News }\end{array}$ \\
\hline
\end{tabular}




\begin{tabular}{|c|c|c|c|}
\hline May & 261 pcs & $\begin{array}{l}\text {-The Mining Company could } \\
\text { not explain the reason of the } \\
\text { fire, } \\
\text {-The Mining Company did not } \\
\text { take required precautions } \\
\text { (Sensors, electricity, etc.), } \\
\text {-Closing of the Life Chambers } \\
\text { in the mine, and ignoring the } \\
\text { opening of new ones, } \\
\text { - Not solving the problem of } \\
\text { subcontracting in Soma Coal } \\
\text { Mine Company, } \\
\text {-The Executive Board of the } \\
\text { Soma Coal Mine Company did } \\
\text { not provide satisfactory } \\
\text { answers to the questions }\end{array}$ & 34 \\
\hline June & 34 & $\begin{array}{l}\text {-All the responsibilities rested } \\
\text { solely on the shoulders of the } \\
\text { employer in Soma Disaster, } \\
\text {-The precautions were not } \\
\text { taken to cover the needs of } \\
\text { the emplovees. }\end{array}$ & 11 \\
\hline July & 35 & $\begin{array}{l}\text { - Closing of the Life } \\
\text { Chambers in mines and } \\
\text { ignoring the opening of new } \\
\text { ones }\end{array}$ & 3 \\
\hline
\end{tabular}

Between the dates May 14, 2014 and August 11, 2014 when the Soma Disaster took place, the number of the pieces of the direct news in Milliyet Internet Newspaper was 330, and the number of the ones about the institutional management crisis was 48 . When the news on institutional management crisis was analysed, it was observed that there were mostly criticisms on the management in general.

The news on management crisis were as follows in general; the required precautions were not taken by the management; the Life Chambers, which were needed in the face of a possible disaster, were closed, which was a handicap for the management; the required conditions were not provided for the employees; and the management remained silent when questions were asked by the families of the dead employees.

Table 2. Hürriyet Internet Newspaper News Content Analysis and Findings (14.5.2014 - 12.8.2014)

\begin{tabular}{|c|c|c|c|}
\hline Month & $\begin{array}{c}\text { The News on } \\
\text { comn }\end{array}$ & News Topics & $\begin{array}{c}\text { Management } \\
\text { Crisis News }\end{array}$ \\
\hline
\end{tabular}




\begin{tabular}{|c|c|c|c|}
\hline Mayıs & 296 & $\begin{array}{l}\text { - The Mining reports } \\
\text { mentioned that death came } \\
\text { in plain sight, and } \\
\text { precautions were not taken, } \\
\text { - The claim that there was a } \\
\text { sabotage was mentioned, } \\
\text { - According to the grieving } \\
\text { wives, the bosses should be } \\
\text { sent to prison, } \\
\text { - Coal mining company } \\
\text { lawyer left the press release } \\
\text { uncompleted, } \\
\text { - The protests of the sub- } \\
\text { contracted employees, } \\
\text { - The computer system } \\
\text { warned the managers twice } \\
\text { about the disaster, } \\
\text { - The General Manager and } \\
\text { the CEO blamed each } \\
\text { other, } \\
\text {-According to the reports of } \\
\text { TEPAV, there were } 2 \\
\text { thousand } 64 \text { children }\end{array}$ & 16 \\
\hline June & 70 & $\begin{array}{l}- \text { The activities of the } \\
\text { employees who did not } \\
\text { receive payment, } \\
\text { - Management mentioned } \\
\text { that the salaries of the } \\
\text { employees were paid by } \\
\text { the Opposition Parties, } \\
\text { - It was claimed that clean } \\
\text { air was given to the gas } \\
\text { sensors in Soma. }\end{array}$ & 5 \\
\hline July & 60 & $\begin{array}{l}\cdot \text { Closing of the Life } \\
\text { Chambers in mines } \\
\text { and ignoring the } \\
\text { opening of the new }\end{array}$ & 2 \\
\hline
\end{tabular}

Between the dates May 14, 2014 and August 11, 2014 when the Soma Disaster took place, the number of the pieces of the direct news in Hürriyet Internet Newspaper was 426 , and the number of the ones about the institutional management crisis was 23 . When the news on institutional management crisis was analysed, it was observed that there were mostly criticisms on the management having not taken the required precautions although the computer systems warned them twice, there were children employees, the salaries were not paid on time, there were conflicts within the management, the company lawyer did not inform the public and the families of the dead employees about the flow of the case.

Table 3. Newstürk Newspaper News Content Analysis and Findings (14.5.2014 - 12.8.2014)

\begin{tabular}{|c|c|c|c|}
\hline Month & News on Soma & News Topics & $\begin{array}{c}\text { Management } \\
\text { Crisis News }\end{array}$ \\
\hline
\end{tabular}




\begin{tabular}{|c|c|c|c|}
\hline May & 185 & $\begin{array}{l}\text {-The owner of the company } \\
\text { spoke for the first time and } \\
\text { said, "I also have the same } \\
\text { information as you", } \\
\text {-There was interesting news } \\
\text { on Soma Case made by a } \\
\text { French TV Channel, } \\
\text {-It was claimed that most } \\
\text { probably, the responsibility } \\
\text { of the disaster would be put } \\
\text { on the company manager, } \\
\text { who died, } \\
\text {-The reason of the fire in the } \\
\text { Coal Mine was not } \\
\text { explained properly by the } \\
\text { company management, } \\
\text {-Specialists stated that it } \\
\text { was possible that the dead } \\
\text { employees could actually be } \\
\text { rescued alive, } \\
\text { - The minister stated that } \\
\text { there were children } \\
\text { employees, } \\
\text { - The Management stated } \\
\text { that the reason of the fire } \\
\text { could not be explained in }\end{array}$ & 12 \\
\hline June & 16 & $\begin{array}{l}\text {-The management said, } \\
\text { "There was a fire in our } \\
\text { mine which was not } \\
\text { previously experienced, } \\
\text { and it cannot be } \\
\text { explained". }\end{array}$ & 3 \\
\hline July & 8 & - & - \\
\hline
\end{tabular}

Between the dates May 14, 2014 and August 11, 2014 when the Soma Disaster took place, the number of the pieces of the direct news in Newstürk Internet Newspaper was 209, and the number of the ones about the institutional management crisis was 15. When the news on Institutional management crisis was analyzed, it was observed that there were mostly criticisms on the management stating that it did not have detailed information on the disaster, international media made interesting news on "Soma Case", the management stated, "there was a fire in our mine which was not previously experienced, and it cannot be explained".

\subsection{Result and Evaluations}

It was determined that there was a total of 965 pieces of news about the Soma Case, which took place on May 14, 2014, in Milliyet, Hürriyet and Newstürk newspapers, which had the highest circulation rates in the field of Internet Journalism in Turkey between the dates May 14, 2014 and August 2, 2014. It was also determined that 86 pieces of news were on company management crisis. It was observed as a result of the analyses that the news on the Institutional management crisis was about not taking the required safety precautions on due time, the Life Chambers were closed and new ones were not opened, children were employed in the mine, the public and the families of the employees were not informed on due time, the salaries of the employees were not paid on due time, the reason of the fire that caused the disaster was not explained in detail, and the company management could not manage the crisis well. 
It was observed that the news and interpretations were generally about the fact that the "Soma Coal Mine Executive Board" did not inform the public and the media on due time, considered the media as an opponent, and did not provide a positive institutional identity and image. The "Informing the Public Model" of Grunig and Hunt is very important in the crisis managements. According to the news analysed, the company did not have a media and public relations unit, and this caused a great tension in the public opinion, in the families of the employees who died in the disaster, and in the media.

Tables Legend

Table 1, 2 and 3 show the Content Analysis and Findings in Milliyet Hürriyet and Newsurk Internet Newspapers, respectively.

\section{References}

[1] Asunakutlu, T. Safran, B. Tosun, E. (2003). Kriz Yönetimi Üzerine Bir Araştırma, Dokuz Eylül Üniversitesi, SBE Dergisi, Cilt 5, Sayı 5.

[2] Atabek, N. (1998). Gündem Belirleme Yaklaşımı, İstanbul Üniversitesi İletişim Fakültesi Dergisi, Sayı 7.

[3] Demirtaş, H. (2016). Kriz Yonetimi. Kuram ve Uygulamada Eğitim Yönetimi, Yıl 6, Sayı: 23, 2000. Ertekin, İrfan, Mükemmellik Kuramı Açısından Kurumsal İletişim Algısı, İstanbul Aydın Üniversitesi, İletişim Çalışmaları Dergisi, Yıl 2 Sayı 3.

[4] Gül, M. \& Cengiz, G. (2016). Gündem Belirleme Kuramı Bağlamında Azerbaycan ve Türkiye'de Siyasal Partilerin Sosyal Medya Kullanımları, International Journal of Social Science, Number 50.

[5] Görkem, Ş. (2013). Kuramda ve Uygulamada Kurumsal İletişim, Yayınlanmamış Doktora Tezi, İstanbul.

[6] Grunig, J. (2005). Halkla İlişkiler ve İletişim Yönetiminde Mükemmellik. Rota Yayınları.

[7] Mc Quail, D. \& Windahl, S. (1993). İletişim Modelleri, Çeviren: Mehmet Küçükkurt, İmaj Yayınları, 1993.

[8] Karcıoğlu, Fatih, Timuroğlu, M.Kürşat, Çınar, Orhan; Örgütsel İletişim ve İş Tatmini İlişkisi: Bir Uygulama, Yönetim, Yıl 20, Sayı 63, 2009.

[9] Kuyucu, Mihalis, Gündem Belirleme Teorisi Bağlamında Radyo Mecrasının Müzik Kamuoyunu Belirleme Gücü, Proceedings of SOCIOINT 2016, $3^{\text {rd }}$ International Conference on Education, Social Sciences and Humanities, 2016.

[10] Örnek, Ali Şahin, Aydın, Şule; Kriz ve Stres Yönetimi, Ankara, Detay Yayıncılık, 2006.

[11] Patan, Günseli Nilhan, İşletmelerde Kriz Yönetimi ve Stratejisinin Önemi, Selçuk Üniversitesi SBE, Yayınlanmamış Yüksek Lisans Tezi, 2009.

[12] Peltekoğlu, Filiz Balta; Halkla Illişkiler Nedir?, İstanbul, Beta Yayıncılık, 2012.

[13] Tunçel, Hakan; Halkla İlişkiler Alanı Olarak Kurum İçi İletişim: Türkiye ve İngiltere Halkla İlişkiler Sektörlerinde Karşılaştırmalı Bir Araştırma, Yayınlanmamış Doktora Tezi, İstanbul, 2007.

[14] Yüksel, Erkan, "Kamuoyu Oluşturma" ve "Gündem Belirleme" Kavramları Nerede Kesişmekte, Nerede Ayrılmaktadır?, Sosyal Bilimler Dergisi (1), 2007.

\section{Internet References}

[1] http://www.alexa.com

[2] http://www.milliyet.com.tr

[3] http://www.google.com.tr 